УДК 37:005.336.2

DOI:

Шулюк Надія Іванівна,

аспірантка кафедри практичної психології,

Криворізький державний педагогічний університет,

м. Кривий Ріг, Україна

ORCID ID 0000-0003-3365-5938

naduashyl@gmail.com

\title{
ДОСВІД ПРОФІЛЬНОЇ ОРІСНТАЦІЇ НА ОСНОВІ СПЕЦІАЛІЗОВАНИХ ОНЛАЙН-РЕСУРСІВ
}

\begin{abstract}
Мета цієї публікації - аналіз досвіду зарубіжної та вітчизняної профільної орієнтації та подальшої профорієнтаційної роботи за допомогою онлайн-сервісів, що допоможе системі освіти в подальшому забезпечити застосування моделей профільного навчання та сприяти розв'язанню проблем учнів, батьків і суспільства. На основі порівняльного аналізу інформації 3 різних джерел показано специфіку профільної та профорієнтаційної роботи зі старшокласниками у Франції, США, Україні, Росії. Зроблено спробу узагальнити принципи організації психолого-педагогічної допомоги у профільному навчанні та впровадженні професійних моделей самовизначення старшокласників на основі онлайн-засобів. Зокрема, виявлено кілька сучасних тенденцій. Так, у США та Франції ознайомлення дітей зі світом професій починається вже у молодшій школі, а далі, щодо старшої ланки школи, діє система профільного орієнтування, яка передбачає можливість зміни напряму освіти за обраним профілем $з$ різних підстав. Для всіх зарубіжних схем профорієнтаційної роботи типовою $є$ організація безперервного профільного орієнтування, що триває протягом усього періоду шкільного навчання: спостереження за досягненнями, схильностями і захопленнями дітей, складання їхнього портфоліо та облік усіх цих відомостей у процесі подальшого профконсультування і відбору абітурієнтів. У профільному та професійному орієнтуванні акцент робиться на відборі здатних освоювати складні наукомісткі технології учнів, що мають явний потенціал професійного зростання та особистісного розвитку. Сучасні IT-технології та спеціалізовані онлайн-платформи розглянуто як ефективні інструменти надання таких психологічних послуг учням та їхнім батькам, а також методичної підтримки педагогам. Завданням подальших досліджень може стати пошук шляхів розв'язання проблеми використання онлайн-ресурсів у школах на основі розробок Міністерства освіти і науки України, створення нових онлайн-платформ для українських шкіл.
\end{abstract}

Ключові слова: зарубіжний досвід онлайн-профорієнтації та профільне орієнтування; онлайн-профорієнтація в Україні; інтернет-ресурси для профорієнтації.

\section{EXPERIENCE OF PROFILE ORIENTATION ON THE BASIS OF SPECIALIZED ONLINE RESOURCES}

\author{
Nadiya I. Shuliuk, \\ Ph.D. student of the Department of Practical Psychology, \\ Kryvyi Rih State Pedagogical University, \\ Kryvyi Rih, Ukraine \\ ORCID ID 0000-0003-3365-5938 \\ naduashyl@gmail.com
}

The purpose of this publication is to analyze the foreign and Ukrainian experience in profile orientation and further career guidance work by means of online services. This must be helpful for 
education system to furtherly provide models of profile education, and solve the problems of students, parents and society. Based on a comparative analysis of information from various sources, it is shown the specifics of profile and career guidance work for high school students in France, the USA, Ukraine, Russia. It is made the attempt to generalize the organization principles in psychological-pedagogical assistance in the profile education, and in the implementation of selfdetermination's professional models in high school students due to the online means. There are identified several modern trends. In the USA and France, children's acquaintance with the world of professions begins in primary school, and then there is a system of specialized guidance for senior school. This system claims the possibility to change the direction of education according to the chosen profile on various grounds. There is a typical organization of continuous career guidance in all foreign schemes of profile orientation which lasts throughout the school: monitoring the achievements, aptitudes, and hobbies of children; compiling their portfolio; and taking into account all this information in further career counseling, and selection of university applicants. In profile and professional orientation, the emphasis is on the selection of students capable of mastering complex knowledge-intensive technologies that have a clear potential for professional growth and personal development. Modern IT resources and specialized online platforms are presented as effective tools to provide such psychological services for students and their parents, as well as to provide methodological support to educators. The further research perspective is to find a solution to use profile orientation online resources in schools, based on the Ministry of Education and Science of Ukraine implementations; to develop new career guidance online platforms for Ukrainian schools.

Keywords: profile orientation; career guidance; online career guidance; internet resources for profile orientation.

Постановка проблеми. Система профільного орієнтування та профконсультування має розвиватися разом зі світовим досвідом застосування IT-технологій. Натомість у школах України фактично не використовують онлайн-ресурси, сервіси та освітні платформи для вирішення завдань профорієнтації та побудови індивідуальних освітніх траєкторій учнів. Винятком є термінали служби зайнятості, встановлені кілька років тому в багатьох школах. Разом 3 тим інформаційна база та алгоритми використання таких пристроїв стрімко втрачають актуальність. Відтак постає потреба як у розробленні сучасних онлайн-платформ, так і у впровадженні новітніх ІТ-технологій для спеціалізованої допомоги в аспекті профільного та професійного орієнтування. Сучасні старшокласники, користуючись інтернетом, могли б отримати доступ до нової інформації відповідно до власних запитів щодо професій, допрофільної підготовки та оптимальної саме для них освітньої траєкторії. Такі країни, як Франція, США, Японія, Росія, вже упровадили спеціалізовані курси в шкільну програму задля швидшого та більш ефективного орієнтування у світі професій та побудови індивідуальної освітньої траєкторії учнів.

Аналіз останніх досліджень і публікацій, виокремлення нерозв'язаних частин загальної проблеми. Доступ до ресурсів інтернету розв'язує проблему того, що інформація в галузі ринку праці та варіантів набуття освіти має властивість швидко змінюватися, застарівати і постійно потребує уточнення. Великий обсяг інформаційних матеріалів 3 питань освіти і профорієнтації може стати серйозним стимулом у роботі педагогів, психологів, а також допомогти старшокласникам та їхнім батькам оптимально вирішувати питання, пов'язані з навчанням і вибором профілю навчання у старшій школі. Можливості використання онлайн-консультування та доступу до інформаційних ресурсів на спеціалізованих платформах та сайтах представлено в роботах С. Григор'єва, В. Гриншкуна, Ю. Царапкіної I А. Лебедєвої (Царапкина, \& Лебедева, 2016, с. 207-212).

У системі надання послуг консультування для молоді Фінляндія наразі активно впроваджує IT-технології в побудові індивідуальних кар'єрних трендів. Фінські дослідники J. Kettunen, R. Vuorinen, J. Sampsonen (2013) показали, як соціальні мережі допомагають у побудові кар'єри через поширення інформації, надання різноманітного переліку послуг, спільний пошук кар'єрного шляху, або «со-careering». «Co-careering», або «спільна побудова кар'єри», - концепція, запропонована J. Kettunen 2015 р., яка передбачає розвиток кар'єри в онлайн-середовищі шляхом обміну досвідом, допомоги одне одному, обміну рекомендаціями 
і конструктивного вирішення питань серед членів інтернет-спільноти. Отже, Фінляндія має позитивний досвід використання IT-технологій у вибудовуванні індивідуальних кар'єрних траєкторій. На основі результатів дослідження, проведеного колективом авторів, зокрема J. Kettunen, R. Vuorinen, O. Ruusuvirta (2016), виділено види потенціалу IT-сектору в реалізації профорієнтаційної діяльності. Ці напрямки містять обгрунтування використання IT-технологій у профорієнтації; доступ до IT-технологій; оцінку функціонування IT-сектору; застосування кар'єрних онлайн-сервісів; особливості фінансування тощо. Кожен ыз цих потенціалів фрагментований за напрямками використання IT-сектору у сфері профорієнтації. Так, наприклад, використання IT-сектору розглядається як засіб для поширення інформації; засіб комунікації для користувача; простір для побудови кар'єрних сервісів; простір для реформ та змін.

Метою статті є огляд різних варіантів інтернет-сервісів, які вже успішно працюють як за кордоном, так і в Україні. На державному рівні професійна орієнтація, що являє собою науково обгрунтовану систему заходів, яка сприяє вибору індивідуальної освітньої траєкторії у старшій школі та професійному самовизначенню особистості, повинна обов'язково використовувати сучасні IT-технології. Профільне орієнтування та профорієнтаційна робота мають проходити не тільки в школі, а й в установах додаткової освіти для дітей і підлітків, у територіальних центрах профорієнтації молоді та психологічної підтримки населення.

Виклад основного матеріалу дослідження. У багатьох країнах $\mathrm{CC}$ діє державна система комплексних дій 3 надання консультативних послуг різним категоріям оптантів: школярам, молоді та дорослим безробітним. Лідером у сфері профорієнтації можна вважати Францію. Оптанти мають альтернативу: обрати приватну систему профорієнтації або ж державну. Також функціонує позашкільна профорієнтація, до якої належать державні служби, що контролюються різними міністерствами (Шамсутдинова, \& Павлова, 2007). Основою побудови профільного орієнтування та профорієнтаційної роботи $є$ широке інформування про можливості вибору роду занять. Таке інформування юних громадян забезпечує Національне бюро інформації за освітою i професіями (Office national d'information sur les enseignements et les professions - ONISEP), що є структурою Міністерства освіти Франції. У країні функціонує ціла мережа спеціалізованих центрів профорієнтації та відповідних онлайн-сервісів, яка тісно співпрацює 3 асоціаціями батьків, профспілками, біржами праці та іншими державними і приватними структурами, що розв'язують проблеми зайнятості населення. Працівниками таких центрів $є$ висококваліфіковані фахівці - радники 3 профорієнтації, які мають спеціальну профільну освіту. Вони наділені необхідними правами й можуть направляти молодих людей на навчання відповідно до їхніх інтересів і здібностей в IT-галузі економіки, де спостерігається кадровий дефіцит.

Використання IT-технологій у профорієнтації є однією з державних програм у США. Зокрема, тут функціонує онлайн-система, яка охоплює тестові батареї, спеціалізовані щодо різних професій. Наприклад, система O*NET (Occupational Information Network) - це безкоштовна професійна інформаційна система, база даних якої (onetonline.org) містить сотні визначень професій. Ї̈ мета - допомогти старшокласникам, студентам, підприємствам i фахівцям з розвитку робочої сили ознайомитися із сучасною сферою праці в Сполучених Штатах. Система O*NET функціонує в країні з 1998 року. Інформація про кожну професію містить такі пункти: зміст діяльності, умови роботи, відповідність кваліфікаційним вимогам, засоби діяльності, вимоги до професійних якостей, професійна освіта, медичні протипоказання, фамільні професії, а також перелік навчальних закладів, у яких готують тих чи інших фахівців. Щоб школярі могли ознайомитися зі світом професій, до перегляду пропонуються також 60-секундні відеоролики, що розповідають про зміст професій, які цікавлять, та про навчальні заклади, де їх можна здобути.

Система O*NET - це гнучка цифрова база даних, яка дає змогу користувачам налаштувати дані під себе. Вона відповідає потребам інформаційного суспільства та обходиться державі й користувачам набагато дешевше, ніж друкована книга. Систему легше оновлювати в міру надходження нових даних. В анотації Міністерства праці США 
платформу O*NET представлено як базу даних професійних вимог і атрибутів працівника. Вона описує професії під кутом зору необхідних навичок і знань, як виконується робота $\mathrm{i}$ якими $\epsilon$ типові робочі параметри. Вона може використовуватися різними категоріями оптантів, зокрема школярами, консультантами служби Гайденс, фахівцями з підбору кадрів.

Окрім професіографічного опису, O*NET надає інформацію про особисті вимоги: навички й знання, необхідні для виконання роботи. Серед інших даних - особисті характеристики: здібності, інтереси й цінності, необхідні для виконання роботи; вимоги до досвіду: навчання, рівень ліцензування та досвід, необхідний для роботи; вимоги до роботи: робоча діяльність і контекст, включаючи фізичні, соціальні та організаційні чинники, що впливають на роботу; ринок праці: професійні перспективи й шкала оплати праці.

У нашій країні наразі створено безкоштовну державну шкільну систему профорієнтації, яка надає консультації батькам, учителям та учням у межах шкіл. На жаль, потенційні роботодавці не квапляться приходити до шкіл та розповідати про свої вакансії. Про чинну в японських школах систему професійних проб в українській школі знають не всі; учителі та шкільні психологи не уявляють, що таке можливо. Кваліфікацію вчителів та психологів для кардинального реформування профільного орієнтування та профорієнтації необхідно підвищувати, але не їхнім власним коштом, а шляхом упровадження державних курсів з профорієнтації.

Серед варіантів використання інформаційних технологій відзначимо можливості використання онлайн-платформи профорієнтації «Magellano Університет». Вона була розроблена у 2015 році за сприяння проєкту ООН в Україні. В іiі основі - європейська методика професійної орієнтації для підлітків «Magellano University». Розробником тесту і представником в Україні є італійська компанія «Giunti Psychometrics». Методику «Magellano Університет» визнано в Європі та сертифіковано в Україні. Міністерство освіти і науки України рекомендує цю методику в профорієнтації учнів.

Tест «Magellano Університет» пропонує масштабний психологічний аналіз інтересів, нахилів та здібностей, ставлення і мотивації до навчання, аналіз інших факторів, що впливають на професійну діяльність. На сайті підліток та його батьки можуть отримати додаткову інформацію, яка суттєво полегшує прийняття остаточного рішення щодо вибору майбутньої професії. Тестування допомагає виявити схильності й здібності підлітка до різних видів діяльності; мотивувати старшокласника самостійно зробити вибір освіти, тобто самостійно прийняти своє, можливо, перше життєво важливе рішення; побудувати стратегію підготовки до вступу до ЗВО на підставі результатів тестування; досягти взаєморозуміння між батьками й підлітком щодо вибору ним подальшої освіти. Тестову батарею розроблено для старшокласників, випускників шкіл, середніх спеціальних навчальних закладів, абітурієнтів, які вагаються щодо правильності попереднього вибору. Вік учасників тестування - від 15 років до 22 років.

Українська адаптація тесту у 2011-2012 роках була проведена групою психологів (О. Бурлачук, К. Рахубовська, В. Шаповалов) під керівництвом доктора психологічних наук, дійсного члена НАПН України, професора Л. Бурлачука. Система пропонує 5 модулів, 3поміж яких слід вибрати варіант відповіді; тестування триває в середньому 1,5 години. Сайт пропонує підтримку фахівця, який допоможе проаналізувати звіт тестування, надати скайпом консультацію. Ця система $є$ платною, вартість тестування і консультації - 1500 грн. Альтернативної системи онлайн-профорієнтації в Україні наразі немає.

Утім, згадаймо ще один сертифікований сайт комп'ютеризованого профорієнтаційного комплексного тестування «Профорієнтатор-UA», адаптований для України (свідоцтво про реєстрацію авторського права № 47521, схвалений Міністерством освіти й науки для використання в закладах загальної середньої освіти). Розробниками програми стали Т. Руденко, Я. Каплуненко, Е. Вертинська і Т. Романцова. На сайті proforientator.com.uа пропонуються послуги тестування; вони платні, ціна варіює залежно від віку оптанта. Тестування проводиться спеціалістами в комп'ютерному класі, з батьками укладається договір про співпрацю. Профорієнтація для школярів 13-18 років та їхніх 
батьків проводиться на базі закладів вищої освіти, таких як Міжрегіональна академія управління персоналом (МАУП); Уманський національний університет садівництва (УНУС); Донбаський інститут техніки та менеджменту Міжнародного науково-технічного університету імені академіка Юрія Бугая. Спеціаліст проводить бесіду-інструктаж, потім тестування.

Тексти інструкцій з'являються перед оптантом на моніторі ПК перед кожним блоком «Профорієнтатор-UA». Тест містить різні питання: це і розв'язування задач, і вибір найбільш привабливих альтернатив, оцінка об'єктів за заданим параметром, вибір варіантів поведінки в тих чи інших ситуаціях. У структурі тесту є три блоки: перший - інтереси, другий здібності, третій - особистісні якості. Перший і третій блоки пред’являються без обмеження часу, на виконання завдань другого блоку (субтест на структуру здібностей) відводиться 40 хвилин. Загалом тест містить 200 питань. На виконання всіх завдань (усього тесту) потрібно в середньому близько 60 хвилин. Результати надаються у вигляді шкального профілю (інтереси, здібності, особистість), а також діаграми (профіль навчання). Оптант після проходження тесту отримує результат у друкованому вигляді. Наводиться перелік відповідних професій, до кожного блоку і до всього тесту - 100 професій (переважно вища професійна освіта), перелік предметів зовнішнього незалежного оцінювання до кожної професії, інтерпретація результатів за шкалами тесту; також представлено блок розвитку, рекомендовані тренінги.

На цьому ж сайті пропонують опитування за методикою «Профнавігатор». Методика спрямована на профорієнтацію школярів середньої школи та надання допомоги у виборі профілю навчання й варіантів додаткового розвитку (гуртків і секцій). Час виконання методики $\sim 40$ хв. Представлено три блоки тесту: мотивація та інтереси, здібності, особистісні якості. Кількість питань - 130. Результати тестування надаються у вигляді шкального профілю (інтереси, здібності, особистість). Також програма створює діаграму (профіль навчання). Надається перелік відповідних гуртків та секцій (за всім тестом - 60 варіантів додаткового розвитку й навчання), а також інтерпретація результатів за шкалами тесту.

Для підлітків 13-16 років пропонується методика «Профмайстер», спрямована на допомогу у виборі професії та профілю навчання в системі середньої спеціальної освіти. Час тестування - 30 хв. Кількість блоків тесту - 2: перший блок - умови праці, другий професійні схильності. Кількість тестових завдань - 110. Результати надаються як експертний висновок та опис профілю. У базі даних - 86 професій з описами. Сайт надає послугу індивідуального консультування за результатами тесту. Після обробки результатів адміністратор платформи передає їх психологу, і той запрошує школяра разом з батьками на індивідуальну консультацію. На виході клієнти зазвичай заповнюють бланк «зворотного зв'язку» (висловлюють свою думку про якість послуги).

Щоб оцінити розподіл профорієнтаційних уподобань, ми провели опитування 102 учнів 8-9 класів (порівну дівчат і хлопців) за модифікованим тестом «Гуманітарій чи технар?» на основі матеріалів платформи profkonsultant.ru. Тест допомагає розмежувати інтереси та здібності учня, адже вони можуть не збігатися. Тест складається із 70 питань, вони розділені на категорії: інтереси, гуманітарні здібності (прості), гуманітарні здібності (складні), технічні здібності (прості), технічні здібності (складні), самооцінка. Результати, представлені на рис. 1, 2, показують, що більшість учнів мають виражену спрямованість за одним із напрямів - «гуманітарій» або «технар».

Утім, є група опитаних, у яких немає помітно виражених здібностей - «не гуманітарій і не технар». У тестовій програмі зазначається, що в таких учнів інтерес та здібності виражені в інших сферах, таких як природничо-наукова діяльність, хімія та хімічна промисловість, лабораторна діагностика, спорт або творчі заняття. Така онлайн-діагностика допоможе учневі зорієнтуватись, у якій сфері йому краще реалізовувати потенціал, щоб його інтереси збігалися з вибором профілю навчання в старшій школі. 


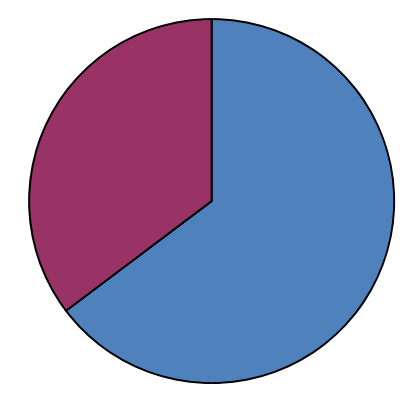

Рис. 1. Розподіл відповідей опитаних за профілем «Гуманітарій»

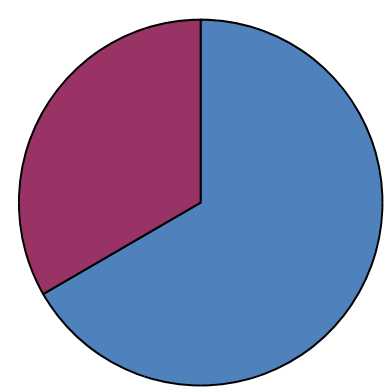

Рuc. 2. Розподіл відповідей опитаних за профілем «Технар»

Відмітимо також проєкт «Професійне середовище», що працює із жовтня 2013 року. Проєкт profsreda.com, створений спочатку для профорієнтації підлітків, 3 часом став посередником між школою і коледжами. Учителі та батьки мають можливість відвідати семінари та майстер-класи. Проєкт є популярним, тому що надає багато можливостей для отримання доступної всім інформації завдяки проведенню заходів у коледжах, на підприємствах і відкритих майданчиках. Куратори проєкту оцінюють його ефективність на підставі підвищення інтересу школярів та абітурієнтів до здобуття робочих спеціальностей і професій. Професії «пізнаються» завдяки спілкуванню 3 професіоналами й майстрами, діяльним пробам і «живому» знайомству з можливими робочими місцями. Усі заходи на платформі проводяться безкоштовно. Проєкт запрошує батьків та учнів на майданчик коледжів для участі в майстер-класах від найкращих майстрів своєї справи. Учні беруть участь у зустрічах з успішними представниками професій, переглядають тематичні фільми.

На сторінці сайту у своєму кабінеті можна ознайомитися із заходами, які відбудуться незабаром, а також дізнатися, які коледжі є в місті. Платформа, наприклад, пропонує пройти тести «Якорі кар'єри», «Як я сприймаю цей світ», анкету «Орієнтація» (І. Соломін). На сторінці учня в електронному кабінеті з'являється інтерпретація результатів після тестування та підказки у формі зображень, на які професії слід звернути увагу. На сайті також представлено тренінги для підвищення кваліфікації педагогів у галузі профільної та професійної орієнтації. Сайт має великий потенціал, для учнів це можливість дізнатися щось про професії, поспілкуватися саме 3 кваліфікованим спеціалістом, який може поділитися своїми знаннями. Важливим є те, що спеціалісти - це фахівці, зацікавлені в тому, що роблять, а учням цікаво слухати та відтворювати те, що їм показують.

Висновки та перспективи подальших досліджень. Онлайн-сервіси (платформи) дають велику перевагу у швидкості обробки, масштабності використання, індивідуальності, можливості пройти тестування та отримати різнобічну інформацію в зручний час і в зручному місці. За такими освітніми платформами, безперечно, майбутнє; перевагою $є$ те, що з часом зникне необхідність часткового фінансування шкільних програм профорієнтації. У багатьох країнах, таких як Франція, США, Японія, Росія, використовують онлайн-засоби для профільного орієнтування, яке є досить успішним. Використання інформаційних технологій дає змогу оцінювати особистісні та психологічні характеристики оптанта відразу за декількома методиками, що виключає необхідність ручної обробки результатів. Система гнучка, у будь-який час може бути доповнена, змінена, оптимізована з урахуванням потреб, що з'явилися. У Франції успішно функціонує Національне бюро інформації щодо освіти i професій, а також ціла мережа спеціалізованих центрів профорієнтації та відповідних онлайн-сервісів, які співпрацюють з учасниками освітнього процесу. У школах США використовується онлайн-система O*NET, яка допомагає у виборі професії. Що ж до українських шкіл, то подібна національна платформа могла б якісно підвищити рівень консультативних та інформаційних послуг. Разом із тим така система не виключає повністю 
роботу класних керівників, педагогів-предметників та психолога у профорієнтаційному напрямку, лише спрощує один з етапів.

В Україні $є$ декілька ресурсів онлайн-тестування для молоді, таких як «Magellano Університет», «Профорієнтатор-UA»; їхні послуги платні. Поточний стан системи професійної орієнтації в Україні наразі на стадії розробки, відчувається брак фахівців у галузі профільного орієнтування та профорієнтаційної роботи. Потребує реалізації система вебінструментів, яка б охоплювала всі необхідні для учня ресурси. У зв'язку з цим гостро постає питання створення моделі освітньої платформи, яка б об'єднувала завдання орієнтування випускників основної школи (профільне орієнтування) та профорієнтаційне консультування, а також створення поновлюваних баз даних інформаційної підтримки профорієнтації інтернет-ресурсами.

Дослідження, проведене нами за модифікованим онлайн-тестом «Гуманітарій чи технар?», свідчить про те, що більшість учнів уже мають чітку профорієнтаційну спрямованість. Створення таких платформ допоможе їм швидше зорієнтуватися, у якому напрямку рухатися далі.

У перспективі наукової роботи - вивчення новітніх розробок у галузі профільного орієнтування, огляд нових баз даних та розроблення комплексних онлайн-опитувальників для створення єдиної бази профорієнтаційної системи.

\section{Список використаних джерел}

Профсреда. Взято из http://www.profsreda.com (07.05.2021).

Тест «Гуманитарий или технарь?». Взято из http://www.profkonsultant.ru/tests/gumanitari-ilitehnar $(07.05 .2021)$.

Царапкина, Ю. М., \& Лебедева, И. И. (2016). Об использовании интернет-технологий в профориентации. European Social Science Journal, $\underline{6}$, 207-212.

Центр тестирования и развития «Гуманитарные технологии». Взято из https://proforientator.com.ua (07.05.2021).

Шамсутдинова, И. Г., \& Павлова, О. И. (2007). Профессиональная ориентация учащихся во Франции. Педагогика, 4, 101-111.

Kettunen, J., Vuorinen, R., \& Ruusuvirta, O. (2016). European Lifelong Guidance Policy Network representatives' conceptions of the role of information and communication technologies related to national guidance policies. International Journal for Educational and Vocational Guidance, 16(3), 327-342.

Kettunen, J., Vuorinen, R., \& Sampson, Jr, J. P. (2013). Career practitioners' conceptions of social media in career services. British Journal of Guidance \& Counselling, 41(3), 302-317.

Magellano University. Взято 3 https://magellano.com.ua (07.05.2021).

O*NET OnLine. Взято 3 https://www.onetonline.org (07.05.2021).

O*NET. Взято 3 https://www.doleta.gov/programs/onet (07.05.2021).

\section{References}

Kettunen, J., Vuorinen, R., \& Ruusuvirta, O. (2016). European Lifelong Guidance Policy Network representatives' conceptions of the role of information and communication technologies related to national guidance policies. International Journal for Educational and Vocational Guidance, 16(3), 327-342. (in English)

Kettunen, J., Vuorinen, R., \& Sampson Jr, J. P. (2013). Career practitioners' conceptions of social media in career services. British Journal of Guidance \& Counselling, 41(3), 302-317. (in English)

Magellano University. Retrieved from https://magellano.com.ua (07.05.2021). (in Ukrainian)

O*NET OnLine. Retrieved from https://www.onetonline.org(07.05.2021). (in English)

O*NET. Retrieved from https://www.doleta.gov/programs/onet (07.05.2021). (in English)

Profsreda [Professional Environment]. Retrieved from http://www.profsreda.com (07.05.2021). (in Russian) 
Shamsutdinova, I. G., \& Pavlova, O. I. (2007). Professionalnaya oriyentatsiya uchashchikhsya vo Frantsii [Professional orientation of students in France]. Pedagogika, 4, 101-111. (in Russian)

Test «Gumanitariy ili tekhnar?» [Test «Humanist or techie?»]. Retrieved from http://www.profkonsultant.ru/tests/gumanitari-ili-tehnar (07.05.2021). (in Russian)

Tsarapkina, Yu. M., \& Lebedeva, I. I. (2016). Ob ispolzovanii internet-tekhnologiy v proforiyentatsii [On the use of Internet technologies in career guidance]. European Social Science Journal, 6, 207-212. (in Russian)

Tsentr testirovaniya i razvitiya «Gumanitarnyye tekhnologii» [Testing and Development Center «Humanitarian Technologies»]. Retrieved from https://proforientator.com.ua (07.05.2021). (in Russian) 